FORTY-THIRD, FORTY-FOURTH, FORTY-FIFTH, FORTYSIXTH, FORTY-SEVENTH AND FORTY-EIGHTH ANNUAL REPORTS OF THE STATE GEOLOGIST

\author{
IOWA GEOLOGTCAL SURVEY \\ Iowa City, Iowa, December 31, 1939
}

To Governor George A. Wilson and Members of the

Geological Board:

GENTLEMEN :

Since the inception of the present Iowa Geological Survey in 1892 there have been but four directors and state geologists. With the exception of two years, 1904-1906, when Frank Wilder served, Professor Samuel Calvin by whom the Survey was founded directed the program from 1892 to 1911. Upon the death of Professor Calvin in-April, 1911, Dr. George F. Kay became director and state geologist. In 1917, Dr. Kay accepted the Deanship of the College of Liberal Arts at the University. In 1934, desiring to devote more time to University administrative duties, he resigned as director and state geologist and upon his recommendation the Geological Board as then constituted appointed the undersigned in these positions. At the same time Dr. A. C. Tester was appointed assistant state geologist, to replace Dr. James $\mathrm{H}$. Lees, retired, who had been assistant state geologist since 1906: The Geological Board accepted Dr. Tester's resignation in 1937 and appointed Dr. H. G. Hershey as assistant state geologist in 1939.

In 1933 the funds of the Survey were reduced, necessitating curtailment of staff, program and publications. The drouths of 1934 and .1936, the new demand for wells for air conditioning purposes, need for restudy of the limestones and shales of the state in a search for raw materials for the manufacture of rock wool insulation, and in 1938 a feverish new interest in the possibility of discovering oil and gas in Iowa so increased the duties of the officers and staff that until now the forty-third to forty-eighth administrative reports and accom-panying papers have not been prepared for publication.

The following report for the years 1934 to 1939 and accompanying 
papers are submitted with the recommendation that they be published as Volume XXXVII.

During the years covered by this report and on this date, the main services rendered have been and are as follows:

\section{Well Water}

Although it is not possible to figure the value of water from wells in dollars and cents, it constitutes by far the most valuable geological resource in Iowa. Used for human consumption, watering livestock, air conditioning, and for various industrial purposes, it touches many phases of state and community life. More than half of the total budget and program of this Survey are devoted to studies and services related to water wells.

Cities, towns, schools, industrial plants, farmers, drillers, and other state departments ask for help in making locations for wells, for forecasts of the depths necessary to obtain a large enough quantity of water of the proper quality to meet their needs in given wells and of the rock formations to be drilled through, and for pumping tests and final checking before the wells are finally accepted and put into use. From 50 to 75 wells, projected or drilling, are continually being so serviced. Much of this work is done in cooperation with the State Department of Health. This work is based on the study of about 50,000 rock samples and more than 1,700 water analyses from more than 1,000 wells previously drilled, logged, and sampled. Taken over by Dr. A. C. Tester from Professor W. H. Norton who retired in 1933, this work is now done by Dr. H. G. Hershey assisted by W. C. Schuldt and M. M. Elias and several graduate students working parttime.

Through cooperative agreement and the matching of funds the work mentioned above has been supplemented since 1938 by the assignment to Iowa of T. W. Robinson, Associate Ground Water Engineer of the U. S. Geological Survey. This new work consists of state-wide studies of fluctuations in ground-water levels and their relation to periods of drouth and abundant rainfall, varying land use practice, heavy and light pumping, etc. More than 80 "observation wells" are now supplying water level records and this number will be increased. It is important that it be discovered whether water is being taken from underground faster than nature restores it, especially in some of our cities where more and more water is being used. 
Knowledge of the permanency of the water supply is essential to the construction or expansion of any water supply system for any purpose.

\section{Stream and Lake Gaging}

Surface water in Iowa streams and lakes is also a valuable asset, although its monetary value cannot be determined. The use and conservation of this water involves certain problems. There is great need for continuous, long-time records of stream discharges during both low water stages and floods. The records are needed in designing bridges, dams, power plants, water supply systems, sewage disposal plants, etc. ; and in planning for flood control, recreation lakes and prevention of soil erosion and the consequent silting of natural and artificial lakes, ditches and flood plains.

During the years covered by this report, the Iowa Geological Survey has been active, along with other interested state departments, in the promotion of a cooperative program of stream and lake gaging. Throughout the country, such work has for many years been done by the Surface Water Division of the Water Resources Branch of the U. S. Geological Survey in cooperation with the states. Until July 1, 1939, state funds for this purpose were contributed, in different amounts in different years, by several of the state departments including the Geological Survey and by the ad interim legislative Committee on Retrenchment and Reform. The 48th General Assembly made a direct appropriation of $\$ 4,500$ a year to the Geological Survey in order that this program might be continued and put on a more permanent and less uncertain basis. Since 1932 the work has been directed by R. G. Kasel, District Engineer of the U. S. Geological Survey, stationed at lowa City.

At the close of 1933 there were 28 gaging stations on Iowa streams and 4 on lowa lakes; at the end of 1939, these numbers had been increased to 64 and 10 respectively. Stage readings are made at each station at least daily and some of the stations are equipped with automatic, continuous recorders. Discharge records are made for each station about once a month.

\section{Oil and Gas}

In spite of the drilling of numerous water wells, some of which have penetrated all possible oil and gas producing horizons all over the state and the drilling of a number of special oil and gas tests, Iowa 
has not so far produced oil or gas in commercial quantities. In 1920, the Iowa Geological Survey published a report entitled "Petroleum and Natural Gas in Iowa" in which the opinion was expressed that although no portion of the state could be considered as really promising "wild cat" territory, about twenty counties in south central and southwestern Iowa were more favorable than the remainder of the state. Later it was recognized that these same counties occupy a portion of the Forest City basin which extends northward into Iowa from northeastern Kansas, southeastern Nebraska and northwestern Missouri. Recently, large quantities of oil have been discovered and produced from an area in south central Illinois known as the Illinois basin. There is enough similarity in the geological conditions of the Illinois and Forest City basins to have created the present interest of oil companies in the Forest City basin. In 1938 and 1939 there was an active leasing campaign not only in the Iowa portion of the Forest City basin but outside of this basin to the north and east. A number of tests have been planned and three are now being drilled.

The policy of the Iowa Geological Survey in regard to the search for oil and gas in this state has always been conservative. The financial risks in any wild cat area are great. It does not seem wise to raise false hopes and to overencourage or overstimulate expensive preliminary surveys and drilling campaigns, especially on the part of local, inexperienced, and under-financed groups. On the other hand this basin should and will be tested. Our policy still is to be conservative, but to be as helpful as possible to all companies, groups and individuals, both inside and outside of Iowa, who really try to bring in oil in the state. Purely promotional schemes are discouraged, but even these are given advice and help once they are under way.

In harmony with this policy the Geological Survey has gladly made available published and unpublished geological data on which the more promising areas can be located, the probable maximum drilling depth in each location can be determined, the thicknesses, depths and characters of possible producing formations can be forecast, "key beds" for core drilling can be selected, etc. Hundreds of requests for reports, maps, sections, logs and samples have been filled. There is also much correspondence and conference in which direct opinions, advice and help are called for and given.

The geological sections of Senate File 328 enacted by the 48th 
General Assembly are being administered by the Geological Survey, according to law. The Act which is designed to safeguard the state's interests without putting. severe restrictions of any sort upon the oil companies or obligating the Survey seriously, appears to be serving the purposes for which it was intended.

It may be a year or several years before Iowa will be either proven to be commercially productive or can safely be condemned as a nonproducing state.

\section{Coal}

The Iowa coal industry is not healthy. This is due partly at least to new competition from oil, gas and hydroelectric power. The problems with which the industry is faced, which are applicable to other states as well as to Iowa, are difficult of solution. Although many of these problems are not geological, the Survey does what it can to improve the coal industry in this state.

In 1936 the Geological Survey published Technical Paper No. 3, Iowa Coal Studies, in which H. L. Olin, University Professor in charge of Iowa Coal Utilization Research and some of his graduate students demonstrated that Iowa coal, if well prepared and properly burned, is not inferior to competing out-of-state coals in b.t.u. content, ash and smoke content, storage qualities, and coking properties.

Beginning in 1932 and continuing through the whole period covered by this report, geological field and laboratory work on the coal beds of the state and the associated clays, shales, sandstones and limestones has been pushed. The coal-bearing formations are being mapped. This work is not only valuable from the standpoint of coal, but its results are extremely useful in the search for oil. This project has been carried on by Professor A. C. Tester, Professor L. M. Cline of the Iowa State College, and a number of graduate students at the University, including M. L. Thompson, D. W. Stookey and E. H. Wenberg. Much progress has been made but the work will be continued for at least a year or two.

The Director of the Survey, Professor Olin and Professor Cline, were members of the Iowa Coal Committee appointed in 1938 by the Iowa State Planning Board at the request of the Governor, the Greater Iowa Commission and the Iowa Coal Institute and participated in the preparation of "Some Aspects of the Iowa Coal Industry," lowa State Planning Board, 1939. 
The history of coal production in Iowa since 1895 , and especially since 1932, is tabulated in papers by H. G. Hershey that appear on pages 375 to 474 of this volume.

\section{New Geologic Map of Iowa}

The most important and useful basis for geological investigations and services of all sorts in any area is the geologic map. Such a map of Iowa by T. E. Savage published in 1905 has long since been out of date and for some years out of print. The most difficult and important task of this Survey administration has been the preparation and publication (1937) of the "Greologic Map of Iowa Showing Distribution of Outcrops of the Indurated Rocks" by Allen C. Tester.

This map on a scale of about 8 miles to 1 inch is lithographed in 7 colors and 26 patterns. It shows the rock formations exposed or immediately underlying the glacial, alluvial and other mantle rock deposits.

Picturing as it does the several sequences, systems, series, groups and formations of rocks in the state and their relation one to another, this map is almost indispensible not only for all the work of the Survey but to all others, inside and outside the state, who are interested in the geology and actual or poteritial mineral and rock resources of Iowa.

\section{Glacial Studies}

Iowa has long been a classic area for the recognition and interpretation of glacial and interglacial deposits. Prior to his death in 1911, Professor Calvin had contributed notably in this field. For 25 years, Dean Kay with the assistance of his graduate students, has been carrying the work forward and is now recognized as a world authority on the Pleistocene or Glacial period. An exhaustive treatise on glacial and interglacial gravels of Iowa by G. F. Kay and P. T. Miller is published in this volume.

The Thirty-seventh Annual Report of the State Geologist, Volume XXXIV, published in 1929, contained as the main paper of the volume, Part I of a monograph on the Pleistocene Geology of Iowa, entitled "The Pre-Illinoian Pleistocene Geology of Iowa," by G. F. Kay and E. T. Apfel. Part II to be entitled "The Illinoian and Post-Illinoian Geology of Iowa" is nearing completion and should be ready for publication in 2 or 3 years.

It should not be understood that this work has no great practical 
value. On the contrary it is necessary to an understanding of the many wells producing water from the drift, to the discovery and development of valuable deposits of sand and gravel, and to the classification and mapping of Iowa soils. In these studies also is found the explanation of the predominantly different topographies in different parts of Towa and corresponding differences in problems of soil erosion, flood control, recreation, etc.

\section{County Reports}

By the close of 1933, all but 7 of the 99 Iowa counties had been surveyed and reports and maps on the geology and mineral resources of each of the 92 counties had been published in volumes of the Annual Reports. Prior to his death in 1935, Dr. James H. Lees had spent considerable time in Adams county, but had not completed the field work or written up the results for publication. This report has now been completed by L. W. Wood of the Iowa State Highway Commission and is published in this volume. In 1938 Audubon county was surveyed by W. H. Yoho, Floyd county by P. H. Nelson, Greene county by W. B. Tapper and Union county by J. H. Russell. These were graduate students who used the results of the surveys as theses at the University. These four county reports await revision, editing and publication.

Only two counties, Calhoun and Shelby, remain unsurveyed.

\section{Rock Wool}

Since 1935 when important interest in the manufacturing of rock wool for insulating purposes first appeared, the Geological Survey has been searching for suitable raw materials in this state. The work is done on a state-wide basis and is not yet complete. Special reports have been prepared for the areas around Dubuque, Clinton, Cedar Rapids, Des Moines, Sioux City, Burlington, Missouri Valley, and Council Bluffs, these being the most favorable places found so far, and for the territory served by each of five of the main Iowa railroads. One plant has already been located and is in operation at Dubuque. Several others should be located in Iowa.

\section{Agricultural Lime}

There is a large and growing need in Iowa for limestone of suffcient purity to be crushed and used as agricultural lime. Although 
Iowa limestones have been studied and mapped in the past, there has been no special survey made by counties, geological formations or otherwise, with this special product in mind. There is known to be an abundance of suitable limestone in many portions of the state.

In connection with the operation of the "liming law" passed by the 47th General Assembly as House File 147, there is need for special geological information concerning outcrops of limestone, its lime content, the thickness of overburden at operating or prospective quarries, etc. County Boards need such data if they are to operate their own quarries and contractors need them in making bids on agricultural limestone for sale to the counties and resale to cooperating farmers.

Current service in this field by the Geological Survey has not been extensive; more of it should be given in the future. In cooperation with the State Planning Board, Appanoose, Clarke, Decatur, Lucas; Monroe and Wayne counties were surveyed for agricultural lime by J. H. Russell and the results were published under the title, "Agricultural Limestone Deposits in the Chariton Basin Counties in Iowa." Outcrops of limestone were located and sampled, samples were analyzed for lime content at the Agricultural Experiment Station at the Iowa State.College, the amount of overburden was estimated, and sites were condemned or recommended. Such work as this should be done on a state-wide basis.

\section{Mineral Production}

Cooperation with the U. S. Bureau of Mines and the National Bituminous Coal Commission in the assembly of annual mineral production statistics has been continued. Figures for cement, clay and clay products, coal, gypsum, limestone, and sand and gravel for the years 1933-38, inclusive, are published in this volume, and also a general summary of mineral production in lowa from 1895 to 1938 , both by $H$. G. Hershey.

Respectfully submitted,

Arthur C. Trowbridge, Director and State Geologist 